control group (non-atopics suffering from functional dyspepsia, chronic gastritis, functional biliary disorders).

Atopy at all the main group patients was confirmed by the elevated serum total IgE detected by the electro-chemiluminescence quantitative determination method. All the patients of the main and control groups had undergone CTACK and TARC detection using the enzyme-linked immunosorbent quantitative determination method.

Association between IgE total, CTACK, TARC and AD phenotypes was determined by the Spearman rank-order correlation (R). For detecting the risks associated with onset of $\mathrm{AD}$ different phenotypes we had determined odds ratio (OR) with $95 \%$ confidence interval (CI) by application of ROC-analysis.

All the data was validated by $p$-value $(p<0.05)$.

There is a significant association between serum total $\operatorname{IgE}$ and CTACK with $\mathrm{AD}$ as mono-nosology - $\mathrm{R}=0.385$ and $\mathrm{R}=0.341 \quad(\mathrm{p}<0.01)$ and with $\mathrm{AD}$ combined with SARC and/or PAR $-\mathrm{R}=0.718$ and $\mathrm{R}=0.397(\mathrm{p}<0.01)$. Risk of onset of $\mathrm{AD}$ as mono-nosology is significantly associated with serum $\mathrm{IgE}>173 \mathrm{IU} / \mathrm{ml}-\mathrm{OR}=$

$8.98[95 \%$ CI 2.53, 31.86], p $<0.001$ and CTACK $\geq$ $3658,5 \mathrm{pg} / \mathrm{ml}-\mathrm{OR}=5.64[95 \%$ CI 1.56, 20.32, $] \mathrm{p}<0.01$. Risk of AD combined with SARC and/or PAR onset is significantly associated with serum CTACK $\geq 4308.8 \mathrm{pg} / \mathrm{ml}-\mathrm{OR}$ $=7.40$ [95\% CI 2.30, 23.76], $\mathrm{p}<0.001$. Risk of progression of $\mathrm{AD}$ as mono-nosology into $\mathrm{AD}$ combined with SARC and/ or PAR is significantly associated with total serum $\operatorname{IgE} \geq$ $1000 \mathrm{IU} / \mathrm{ml}-\mathrm{OR}=16,0$ [95\% CI 2.68, 95.44], $\mathrm{p}<0.001$.

Serum IgE total and CTACK are significantly associated with the studied AD phenotypes.

Risk of $\mathrm{AD}$ as a mono-nosology onset is significantly associated with serum total $\mathrm{IgE} \geq 173 \mathrm{IU} / \mathrm{ml}$ and CTACK $\geq$ $3658,5 \mathrm{pg} / \mathrm{ml}$, AD combined with SARC and/or PAR - serum CTACK $\geq 4308.8 \mathrm{pg} / \mathrm{ml}$.

Risk of progression of $\mathrm{AD}$ as mono-nosology into $\mathrm{AD}$ combined with SARC/and or PAR is significantly associated with serum total $\mathrm{IgE} \geq 1000 \mathrm{IU} / \mathrm{ml}$.

There is no significant association between serum TARC and the risk of $\mathrm{AD}$ phenotypes onset.

\section{THE LONG-TERM MONITORING AND ANALYSIS OF OUTCOMES OF DIFFERENT APPROACHES TO THE MANAGEMENT OF CHRONIC SPONTANEOUS IN ADOLESCENTS}

Vera Kalugina*, L Namazova-Baranova, E Vishneva, P Arimova, L Aslamazyan. 'Research Institute of Pediatrics and Child Health Care Central Clinical Hospital of Russian Academy of Science, Moscow, Russia; ${ }^{2}$ Pirogov Russian National Research Medical University (RNRMU), Moscow, Russia

\subsection{6/archdischild-2021-europaediatrics. 146}

Second-generation of $\mathrm{H} 1$-antihistamines $(\mathrm{H} 1-\mathrm{AH})$ is the main therapy for the chronic spontaneous urticaria (CSU). Omalisumab (Omab) is the only biological, approved for the severe $\mathrm{H} 1-\mathrm{AH}$ resistant CSU in adolescents over

12 years.

Aim: to evaluate different approaches to severe CSU therapy in adolescents and assess achieving of disease control in 3 y period.

Methods The long-term prospective observation study of 34 children with severe CSU (55\% boys, average age 13 y o $(\min 3 ; \max 17,0)$, the duration of disease $-33 \operatorname{mo}(\min 3$; $\max 144$ ); UAS7 - 18 points ( $\min 16$; $\max 24,0$ ) was conducted. All patients received $\mathrm{H} 1-\mathrm{AH}$ for minimum 3 mo.

Patients were randomized in 2 groups. 17 patients of the 1st group were added with Omab to therapy: 55,6\% girls, average age -15 y $(\min 12,0 ; \max 17,0)$; disease duration was 45,2 mo $(\min 3,0 ; \max 144,0)$, the average total $\operatorname{IgE}$ level - 348,2 IU/mL ( $\min 0,8 ; \max 2041,0)$; the average UAS7 at debut -

17,2 points $(\min 16 ; \max 24)$. The course of Omab therapy was $6 \mathrm{mo}, 300 \mathrm{mg} / \mathrm{mo}$ subcutaneously.

17 patients of the 2 nd group maintained alone $\mathrm{H} 1-\mathrm{AH}$ therapy: $64,7 \%$ boys, average age $-10,8$ y (min 3,0; $\max$ $15,0)$; disease duration was $20,5(\min 3 ; \max 72) \operatorname{mo}$, the average total $\mathrm{IgE}$ level $-182 \mathrm{IU} / \mathrm{mL}(\min 20$; $\max 1050)$;

UAS7 at debut - 18 (min 16; $\max 28)$ points.

The efficacy of therapy assessed by urticaria activity score for the 7 days (UAS7).

Results in the 1 st group of patients in 6 mo of Omab therapy UAS7 was $1,6(\min 0 ; \max 20)$ points, $\mathrm{p}<0,05$. After 3 $\mathrm{y}$ of the course Omab therapy UAS7 was 4,5 points, $\mathrm{p}<0,05$.

In the 2 nd group of patients, who received alone $\mathrm{H} 1-\mathrm{AH}$, in 6 mo UAS7 remained at the same level -18 points $(\mathrm{p}<$ $0,05)$. The average UAS7 in $3 \mathrm{y}$ was 12 ( $\min 0 ; \max 26)$ points $(\mathrm{p}<0,05)$.

Thus, in patients receiving Omab UAS7 significantly decreased after 6 mo.

The UAS7 level in the Omab group indicates a greater proportion of children who have achieved disease control. The proportion of children, who have achieved remission during 3 y $(\mathrm{UAS} 7=0)$ : in Omab group $52,9 \%$, in $\mathrm{H} 1-\mathrm{AH}-29,4 \%$ $(\mathrm{p}=0,163)$.

Conclusion Our results indicate the efficacy of Omab in adolescents with

CSU: rapid relief of urticaria symptoms and a greater proportion of adolescents who have achieved disease control, compared with therapy alone H1-AH.

\section{STEVENS-JOHNSON SYNDROME}

Nedim Strukar*, Verica Mišanović, Adisa Čengić, Aida Karačić, Alma Mujić, Emina Ribić. Department of Pediatrics, Travnik County Hospital, Travnik, Bosnia and Herzegovina

10.1136/archdischild-2021-europaediatrics. 147

Stevens-Johnson syndrome (SJS) is a severe mucocutaneous reaction characterized by extensive necrosis and separation of the epidermis. The mucous membranes are affected in over $90 \%$ of patients, usually in two or more different sites. The incidence ranges from 2 to 7 cases per million people per year. Medication use is a leading trigger of Stevens-Johnson syndrome in both adults and children, followed by Mycoplasma pneumoniae infection. The disease begins with flu-like symptoms and fever, followed by the onset of mucocutaneous and skin changes. The diagnosis is based on clinical and histological findings in a patient with a history of previous medication exposure or febrile illness.

A 10-year-old boy presented with fever, cough, and dyspnoea. He was examined ten days before the admission and prescribed with antibiotic.

Physical examination shows dehydration and light dyspnoea, along with mild diffuse bulbar injection of both eyes, and moderate oedema and hyperaemia of the tonsils and pharyngeal mucosa. There was no skin rash. Auscultation of lungs 